\title{
多極参照電極付き単セルを用いた 各種電気化学デバイスの特異現象の解析
}

\section{光田 憲朗，竹村 大吾，原 聡（技術賞・棚橋賞）}

\section{1. 本研究の背景}

1980 年代に，リン酸形燃料電池の世界中の実プラントで, 従来の電気化学手法では解明できない異常腐食に遭遇したが, 『多極参照電極付き単セル』という新たな電気化学手法を考 案して解析することで，七ル面内で，過渡的に電位が異なる 現象が起こるなどの定量的な電気化学的解析が可能になり, 原因の究明と対策につながった。その後, Table 1 に示すよ うに，キャパシタやリチウムイオン電池など，他の電気化学 デバイスでも『多極参照電極付き単セル』を適用し，従来の 電気化学手法では十分には解明できていなかった現象や異常 腐食の原因究明と対策につなげることができた。

Table 1. Specific phenomena of various electrochemical devices clarified by single cells with multi-reference electrodes.

\begin{tabular}{|c|c|c|c|c|}
\hline 略号 & 電気化学デバイス & $\begin{array}{l}\text { Ref } \\
\text { 種類 }\end{array}$ & $\begin{array}{l}\text { Ref } \\
\text { 極数 }\end{array}$ & 解明した現象 \\
\hline PAFC & リン酸形燃料電池 & \multirow[t]{2}{*}{ RHE } & $4 \sim 24$ & $\begin{array}{l}\text { 空気極異常腐食 } \\
\mathrm{CO} \text { 等化合物被毒 } \\
\text { 流路方式の効果 }\end{array}$ \\
\hline PEFC & $\begin{array}{c}\text { 固体高分子形 } \\
\text { 燃料電池 }\end{array}$ & & 4 & 燃料欠乏の影響 \\
\hline EDLC & $\begin{array}{l}\text { 電気二重層 } \\
\text { キャパシタ }\end{array}$ & \multirow{4}{*}{$\mathrm{Li}$} & $3 \sim 8$ & 正極端部異常腐食 \\
\hline LIC & $\begin{array}{l}\text { リチウムイオン } \\
\text { キャパシタ }\end{array}$ & & 8 & $\begin{array}{l}\text { リチウムドープ } \\
\text { 現象 }\end{array}$ \\
\hline HLIC & 複合形キャパシタ & & 8 & $\begin{array}{l}\mathrm{LIC} \cdot \mathrm{LIB} \text { 間電位 } \\
\text { 挙動 }\end{array}$ \\
\hline LIB & リチウムイオン電池 & & $3 \sim 8$ & 正極端部電位挙動 \\
\hline
\end{tabular}

\section{2. リチウムイオン電池での特異現象の解析例 ${ }^{1}$}

リチウイオン電池において，多極参照電極付きLIB 単セル （Fig. 1）を用いて，負極張り出し部や正極張り出し部と中心 部との間で電流が流れ，過渡的に大きく異なる電位になるこ とや，負極に対峙していない正極部（正極張り出し部）が存 在すると, 充放電の繰り返しによって, 電位的にその負極に 金属リチウムが析出する可能性のあることを明らかにした (Fig. 2)。また，インピーダンス測定において，七ル外に参 照電極を配置する場合の正極と負極の端面の僅かなずれが, 大きな影響を及ぼすことなどを明らかにした。

\section{3. まとめ}

異常腐食や金属リチウム析出などの特異現象は，大きなセ ル面積に比べて電極間の距離が短く，イオンが横方向に移動 するのに時間がかかり, 過渡的に電子レベルと電気化学電位

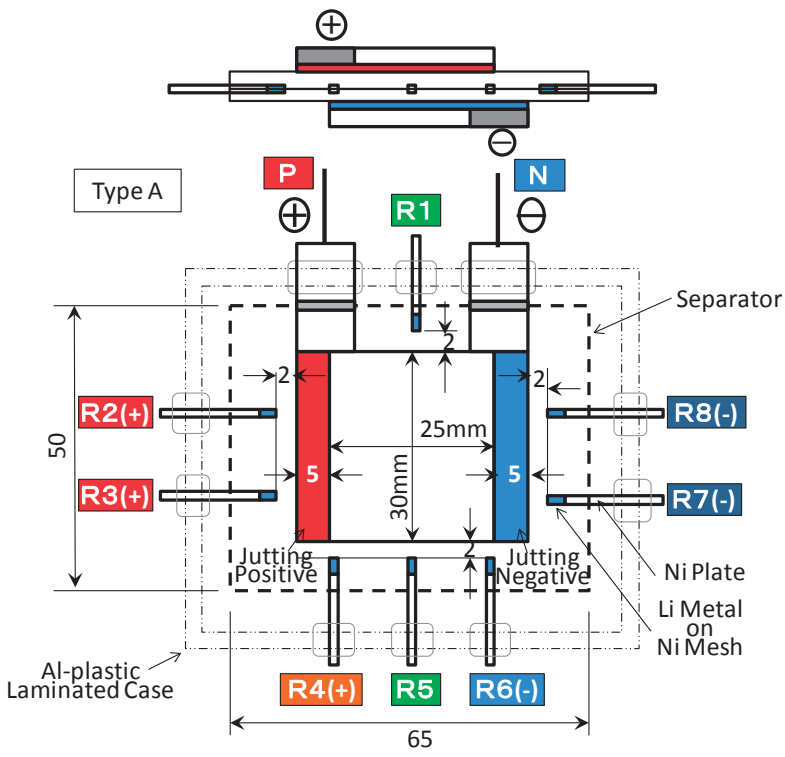

Figure 1. Cross-sectional view and plan view of a LIB cell with 8 -reference electrodes.

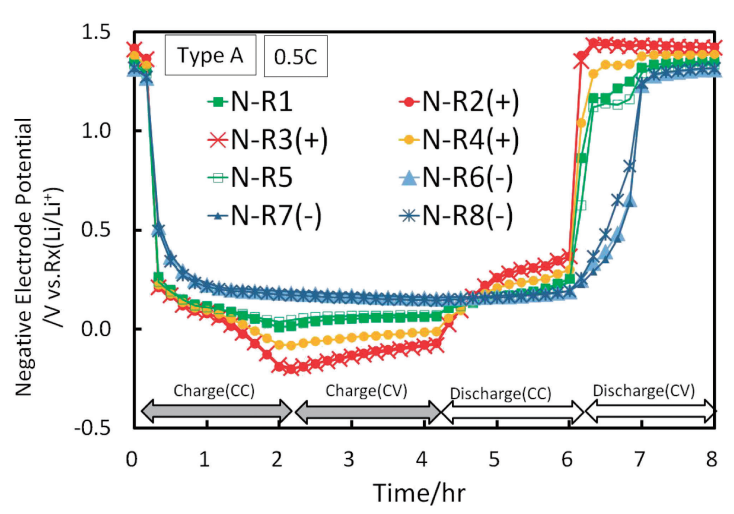

Figure 2. Potential behavior of the negative electrode during charge and discharge.

との関係が場所によって一致しない状況が起こるという実用 機ならではの現象であった。多極参照電極付き単セルを用い ることで，はじめて電気化学的電位の局部的な変化を定量的 に明らかにすることができた。

\section{謝 辞}

本研究は, 村橋俊明元福井工大教授 (元三菱電機) のご指 導により結実させることができました。本紙面をお借りして, 深くお礼申し上げます。

文 献

1. K. Mitsuda, S. Hara, and D. Takemura, Electrochemistry, 84, 861 (2016) 